Original Article

\title{
Development of Aircraft Movement Simulation in Airport Airside Area
}

\author{
M Sadono1,", D Y Putra ${ }^{1}$, S A Harahap ${ }^{1}$ \\ 1 Faculty of Mechanical and Aerospace Engineering, Institut Teknologi Bandung Labtek II Building, \\ Jl. Ganesa 10 Bandung 40132 \\ * Correspondence: mahar65@yahoo.com
}

Received: 20 January 2020; Accepted: 23 April 2020; Published: 30 June 2020

\begin{abstract}
Soekarno-Hatta Intl Airport had become busier every and each year passed. Based on Airnav's data in 2016, there was about 1.200 aircraft movement, included take-off and landing, happened in Soekarno-Hatta Intl Airport in one day. These numerous movements made SoekarnoHatta Intl Airport became the 12th busiest airport in the world based on Airport Council International (ACI). The long queue of the aircraft at the taxiway is deniable and became one of the problems that needs to be resolved. This research would make aircrafts movement simulation in Soekarno-Hatta Intl Airport's taxiway(s) using Rockwell Arena Simulation software. The simulation results would be total taxiing time of an aircraft, which intersection(s) that traffic happened, and the total of aircraft(s) that doing taxi in and taxi out. This simulation would help to determine and evaluate the factors that initiated the queue in the taxiway and modify taxiing route to reduce the traffic. The results of this research can be applied by the airport as a reference for scheduling aircraft's departing or arriving, develop airport airside facility, and to improve taxiing route so the duration of aircraft's taxiing time can be reduced.
\end{abstract}

Keywords: taxiing, taxiway, queue, airport, simulation

\section{Introduction}

Soekarno-Hatta International Airport took a big part in Indonesia's economic growth. Soekarno-Hatta International Airport is the gate to people around the world who went to Indonesia with very purposes, like businesses, diplomatic agreement and also became tourist destinations. These reasons had risen the number of the flight, increase the traffic and aircraft movement in Soekarno-Hatta Intl Airport and made it became the 12th busiest airport in the world based on Airport Council International (ACI) [1]. The traffic at Soekarno-Hatta Intl Airport had delivered it to the last position on the On-time ranking departure performance based on Flightstats website, for August 2018 flights. With total 21.559 flights, the flight that has on-time departure are $51,46 \%$ and the flight that got delayed ( $+15 \mathrm{~min}$.) are $48,54 \%$ [2-3].

The aircraft traffic that happened in Soekarno-Hatta Intl Airport airside become one of the reasons the flight became delayed. The traffic could be seen at the holding bay of taxiway when the aircraft will take-off. This traffic gave a bad impact to the airlines because it would cost them more. Based on Indonesia National Carriers Air Association (INACA), a flight that had delayed for 20 minutes would add cost about $\$ 1.000$ for the extra fuel for longer taxiing time $[4,5]$.

\subsection{Taxiing}

Taxiing is a process to move the aircraft in the ground from one place to another one with its own power. Like when the aircraft move from the terminals to the edge of the runway before 
take-off. Aircraft's taxi speed limited to 20 knots; it also depends on the circumstances. In a straight long taxiway and without obstacle around, the speed could be reached 30 knots. However, remind if the taxi speed over 20 knots, it would need a strong control of the nose wheel to avoid over-controlling-nose-wheel-risk. In the turning side, the speed must be reduced to the speed limits of aircraft when turning, 10 knots [6].

\subsection{Taxiway}

The taxiway is a path for aircraft at an airport that connects runway to the terminal area and service hangars. In some busy airport, that have high aircraft movement, the configuration would be used is the one-way parallel taxiway. This configuration has a purpose to reduce aircraft queue time in taxiway so the aircraft mobility will be faster when it doing landing or take-off. Busy airports also add taxiway in some strategic place along the runway, so the aircraft that just landed could be cleared away quicker from the runway. This type of taxiway called exit taxiway [7].

\section{Methods}

This research would make aircrafts movement simulation in Soekarno-Hatta Intl Airport's taxiway(s) using Rockwell Arena Simulation software. This software already used by many global companies to simulate their problems to resolve the issues and do their business. In this simulation, there will be some assumptions that would be used:

1. The aircraft speed will be assumed as 20 knots, the average speed of aircraft taxiing speed.

2. The reduction of speed and linear acceleration will be assumed none in the taxing process.

3. The runway that would be used in this simulation is the runway on the west side (07L and 07R) for take-off and landing process, which will be in random sequences.

4. The flight that would be simulated are the flight that scheduled between 15.00 WIB to 22.00 WIB based on Soekarno-Hatta Intl Airport west-side-runway historical data.

5. The duration of an aircraft's taxi time from one point to another point using Linear Movement methods.

6. The runway will be used 50 percent to take-off and 50 percent to landing.

7. The distance between the points will be found by using a scale comparison method using Corel Draw software.

\subsection{Simulation's Flow}

The simulation will be using the flow that shows in Figure 1. It would start by inputting the flight data and the distance between taxiway intersection data. The next step is to make algorithms and models of each taxiway segments. After that integrate all the small segments to one big algorithm before running the simulation. If the simulation error, we need to identify the error(s) in the algorithm or the model, and after that fixed the error(s). If the simulation running smoothly, the next step is checking the results. If the data make sense and valid, we can make the conclusion and end the simulation. But if the data do not make sense and/or not valid, so we need to re-check the algorithm and model.

\subsection{Taxiing Route}

Taxiing route is the path that the aircraft used from runway to terminal or the contrary. Every aircraft that will depart from or arrive at every terminal have its own taxiing route. The aircraft that will depart will have a different route with the aircraft that will arrive, although it is from or heading to the same terminal. The taxiing route from 07R and 07L runway based on "Airport Information for WIII" that published by Jeppesen could be seen at Table 1 and Table 2 
International Journal of Aviation Science and Engineering

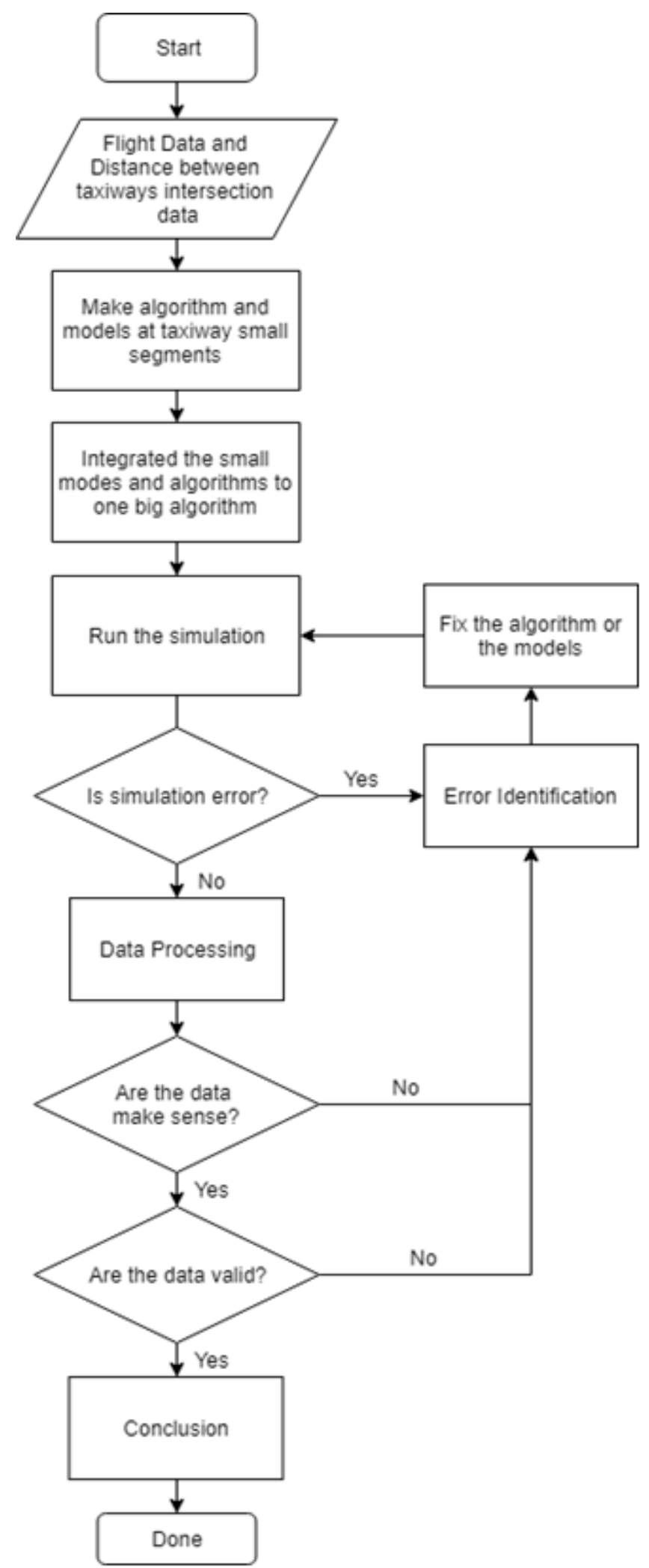

Figure 1. Aircraft movement simulation flow chart. 
Table 1. Taxiing route for departure.

\begin{tabular}{l|l|l|l}
\multicolumn{1}{c}{ DEPARTURE : } & \multicolumn{1}{|c}{ RUNWAY } & \multicolumn{1}{c}{ 07L } \\
\hline \multirow{4}{*}{ TERMINAL } & GATE & \multicolumn{1}{c}{ ROUTE } & \multicolumn{1}{c}{ TAXI ROUTING } \\
\hline \multirow{5}{*}{$3 U$} & NCX & GOLF 6 & NCX - NP1 - NCZ - NP2 - N7 \\
\cline { 2 - 4 } & NC2 & GOLF 5 & NC2 - NP1 - NCZ - NP2 - N7 \\
\cline { 2 - 4 } & NCM & GOLF 4 & NCM - NP1 - NCZ - NP2 - N7 \\
\hline \multirow{5}{*}{2} & NC4 & FOXTROT 2 & NC4 - NP2 - N7 \\
\cline { 2 - 4 } & NCY & ECHO 4 & NCY - NP2 - N7 \\
\cline { 2 - 4 } & NC5 & ECHO 3 & NC5 - NP2 - N7 \\
\cline { 2 - 4 } & NCZ & DELTA 4 & NCZ - NP2 - N7 \\
\cline { 2 - 4 } & NPW & DELTA 3 & NPW - WC2 - NP2 - N7 \\
\hline \multirow{5}{*}{1} & SPW & CHARLIE 8 & SPW - WC2 - NP2 - N7 \\
\cline { 2 - 4 } & SC5 & CHARLIE 7 & SC5 - SP1 - WC2 - NP2 - N7 \\
\cline { 2 - 4 } & SC4 & BRAVO 8 & SC5 - SP1 - WC2 - NP2 - N7 \\
\cline { 2 - 4 } & SCX & BRAVO 7 & SC5 - SP1 - WC2 - NP2 - N7 \\
\cline { 2 - 4 } & SC3 & ALPHA 4 & SC5 - SP1 - WC2 - NP2 - N7 \\
\hline
\end{tabular}

\begin{tabular}{c|l|l|l} 
DEPARTURE : & \multicolumn{2}{|c}{ RUNWAY } & \multicolumn{1}{c}{ T7R } \\
\hline TERMINAL & GATE & \multicolumn{1}{|c}{ ROUTE } & \multicolumn{1}{c}{ TAXI ROUTING } \\
\hline \multirow{4}{*}{$3 U$} & NCX & GOLF 12 & NCX - NP1 - WC1 - SP2 - S7 \\
\cline { 2 - 4 } & NC2 & GOLF 11 & NC2 - NP1 - WC1 - SP2 - S7 \\
\cline { 2 - 4 } & NCM & GOLF 10 & NCM - NP1 - WC1 - SP2 - S7 \\
\hline \multirow{4}{*}{2} & NC4 & FOXTROT 4 & NC4 - NP2 - WC1 - SP2 - S7 \\
\cline { 2 - 4 } & NCY & ECHO 8 & NCY - NP2 - WC1 - SP2 - S7 \\
\cline { 2 - 4 } & NC5 & ECHO 7 & NC5 - NP1 - WC1 - SP2 - S7 \\
\cline { 2 - 4 } & NCZ & DELTA 8 & NCZ - NP1 - WC1 - SP2 - S7 \\
\cline { 2 - 4 } & NPW & DELTA 7 & NPW - WC1 - SP2 - S7 \\
\hline \multirow{5}{*}{1} & SPW & CHARLIE 4 & SPW - WC1 - SP2 - S7 \\
\cline { 2 - 4 } & SC5 & CHARLIE 3 & SC5 - SP1 - WC1 - SP2 - S7 \\
\cline { 2 - 4 } & SC4 & BRAVO 4 & SC4 - SP1 - WC1 - SP2 - S7 \\
\cline { 2 - 4 } & SCX & BRAVO 3 & SCX - SP1 - WC1 - SP2 - S7 \\
\cline { 2 - 4 } & SC3 & ALPHA 2 & SC3 - SP1 - WC1 - SP2 - S7 \\
\hline
\end{tabular}

Table 2. Taxiing route arrival.

\begin{tabular}{l|l|l|l}
\hline TERMINAL & GATE & ROUTE & TAXI ROUTING \\
\hline \multirow{4}{*}{$3 U$} & NCX & GOLF 6A & N1 - NC1 - NCX \\
\cline { 2 - 4 } & NC2 & GOLF 5A & N1 - NP1 - NC2 \\
\hline \multirow{5}{*}{} & & GOLF 5 & N2 - NC2 \\
\cline { 2 - 4 } & NCM & \multirow{3}{*}{ GOLF 4A } & N1 - NP1 - NCM \\
\cline { 2 - 4 } & NC4 & FOXTROT 3 & N1/N2/N3 - NP2 - NC4 \\
\cline { 2 - 4 } & NCY & ECHO 5 & N1/N2/N3 - NP2 - NCY \\
\cline { 2 - 4 } & NC5 & ECHO 4 & N1/N2/N3 - NP2 - NC5 \\
\cline { 2 - 4 } & NCZ & DELTA 4 & N1/N2/N3 - NP2 - NCZ \\
\cline { 2 - 4 } & NPW & DELTA 5 & N1/N2/N3 - NP2 - WC1 - NPW \\
\hline \multirow{5}{*}{1} & SPW & CHARLIE 11 & N1/N2/N3 - NP2 - WC1 - SPW \\
\cline { 2 - 4 } & SC5 & CHARLIE 12 & N1/N2/N3 - NP2 - WC1 - SP2 - SC5 \\
\cline { 2 - 4 } & SC4 & BRAVO 11 & N1/N2/N3 - NP2 - WC1 - SP2 - SC4 \\
\cline { 2 - 4 } & SCX & BRAVO 10 & N1/N2/N3 - NP2 - WC1 - SP2 - SCX \\
\cline { 2 - 4 } & SC3 & ALPHA 6 & N1/N2/N3 - NP2 - WC1 - SP2 - SC3 \\
\hline
\end{tabular}




\begin{tabular}{|c|c|c|c|}
\hline ARRIVAL : & RUNW & & \\
\hline TERMINAL & GATE & ROUTE & TAXI ROUTING \\
\hline \multirow[b]{3}{*}{$3 \mathrm{U}$} & NCX & GOLF 12 & $\mathrm{~S} 1 / \mathrm{S} 2 / \mathrm{S} 3-\mathrm{SP} 2-\mathrm{WC} 2-\mathrm{NP} 2-\mathrm{NC} 4-\mathrm{NP} 1-\mathrm{NCM}-\mathrm{NCX}$ \\
\hline & $\mathrm{NC} 2$ & GOLF 11A & $\mathrm{S} 1 / \mathrm{S} 2 / \mathrm{S} 3$ - SP2 - WC2 - NP2 - NC2 \\
\hline & $\mathrm{NCM}$ & GOLF 10 & $\mathrm{~S} 1 / \mathrm{S} 2 / \mathrm{S} 3$ - SP2 - WC2 - NP2 - NC4 - NP1 - NCM \\
\hline \multirow{5}{*}{2} & $\mathrm{NC} 4$ & FOXTROT 6 & $\mathrm{~S} 1 / \mathrm{S} 2 / \mathrm{S} 3-\mathrm{SP} 2-\mathrm{WC} 2-\mathrm{NP} 2-\mathrm{NC} 4$ \\
\hline & NCY & ECHO 11 & $\mathrm{~S} 1 / \mathrm{S} 2 / \mathrm{S} 3-\mathrm{SP} 2-\mathrm{WC} 2-\mathrm{NP} 2-\mathrm{NCY}$ \\
\hline & NC5 & ECHO 10 & $\mathrm{~S} 1 / \mathrm{S} 2 / \mathrm{S} 3-\mathrm{SP} 2-\mathrm{WC} 2-\mathrm{NP} 2-\mathrm{NC} 5$ \\
\hline & $\mathrm{NCZ}$ & DELTA 11 & $\mathrm{~S} 1 / \mathrm{S} 2 / \mathrm{S} 3-\mathrm{SP} 2-\mathrm{WC} 2-\mathrm{NP} 2-\mathrm{NCZ}$ \\
\hline & NPW & DELTA 10 & $\mathrm{~S} 1 / \mathrm{S} 2 / \mathrm{S} 3-\mathrm{SP} 2-\mathrm{WC} 2-\mathrm{NPW}$ \\
\hline \multirow{6}{*}{1} & SPW & CHARLIE 6 & $\mathrm{~S} 1 / \mathrm{S} 2 / \mathrm{S} 3$ - SP2 - WC2 - SPW \\
\hline & SC5 & CHARLIE 5 & $\mathrm{~S} 1 / \mathrm{S} 2 / \mathrm{S} 3-\mathrm{SP} 2-\mathrm{SC} 5$ \\
\hline & SC4 & BRAVO 5 & $\mathrm{~S} 1 / \mathrm{S} 2 / \mathrm{S} 3$ - SP2 - SC4 \\
\hline & SCX & BRAVO 4 & $\mathrm{~S} 1 / \mathrm{S} 2 / \mathrm{S} 3$ - SP2 - SCX \\
\hline & $\mathrm{SC} 3$ & ALPHA 2 & S3 - SC3 \\
\hline & SC3 & ALPHA 3 & $\mathrm{SI} / \mathrm{S} 2-\mathrm{SP} 2-\mathrm{SC} 3$ \\
\hline
\end{tabular}

Flights that would be simulated are the flights that scheduled between 15.00 WIB to $22.00 \mathrm{WIB}$. This range is chosen because based on the historical data, the west side of the runway is used mainly at these hours. Official website of Soekarno-Hatta Intl Airport shows at that time range the aircraft movement is busier and dominated by the aircraft that approach the airport. It shows the arrival's movement will be busier than the departure's movement.

Table 3. Total arrival and departure at Soekarno-Hatta Intl Airport based on the terminals.

\begin{tabular}{c|c|c}
\hline Terminal & Arrival & Departure \\
\hline $1 \mathrm{~A}$ & 33 & 29 \\
\hline 1B & 36 & 28 \\
\hline 1C & 56 & 36 \\
\hline $2 \mathrm{D}$ & 30 & 22 \\
\hline 2E & 26 & 16 \\
\hline $2 \mathrm{~F}$ & 36 & 27 \\
\hline $3 \mathrm{U}$ & 83 & 61 \\
\hline Total & $\mathbf{3 0 0}$ & $\mathbf{2 1 9}$ \\
\hline
\end{tabular}

\subsection{Entity Input}

The entity input needed at the create module at the software, and it will be based on the total number of flights. The entity input would be a frequency of the aircraft start to depart or arrive in minutes. The triangular distribution would be used, to show the average, minimum, and maximum value. The minimum and maximum value will be picked randomly. Table 4 contains information about the flight's frequency from and to Soekarno-Hatta Intl Airport between time range between 15.00 to 22.00 western Indonesia time (WIB). 
Table 4. The frequency of flight to and from Soekarno-Hatta Intl Airport at 15.00-22.00 WIB

\begin{tabular}{l|c|c|c|c}
\hline \multirow{4}{*}{} & \multirow{3}{*}{ Terminal } & \multicolumn{3}{|c}{ Frequency (minutes) } \\
\cline { 2 - 5 } & Average & Minimum & Maximum \\
\hline \multirow{5}{*}{ Departure } & 3U & 6.5 & 5 & 10 \\
\cline { 2 - 5 } & 2F & 15 & 10 & 20 \\
\cline { 2 - 5 } & 2E & 26 & 15 & 30 \\
\cline { 2 - 5 } & 2D & 19 & 15 & 20 \\
\cline { 2 - 5 } & 1C & 11.6 & 10 & 15 \\
\cline { 2 - 5 } & 1B & 15 & 10 & 20 \\
\hline \multirow{5}{*}{ Arrival } & 1A & 14.48 & 10 & 20 \\
\cline { 2 - 5 } & 3U & 5 & 3 & 7 \\
\cline { 2 - 5 } & 2F & 11.6 & 9 & 14 \\
\cline { 2 - 5 } & 2E & 16.15 & 13 & 16 \\
\cline { 2 - 5 } & 2D & 13.5 & 11 & 16 \\
\cline { 2 - 5 } & 1C & 7.5 & 5 & 10 \\
\hline
\end{tabular}

\section{Results and Discussions}

The results of this simulation have three outputs: waiting time, transfer time, and total time. Waiting time is the time that used by the aircraft to wait on the queue. Transfer time is the time that the aircraft used for taxiing. Total time is the sum of waiting time and transfer time while taxiing.

Table 5. Simulation output of waiting time, transfer time, and total time

\begin{tabular}{|c|c|c|c|c|c|c|c|c|c|}
\hline \multirow{2}{*}{$\begin{array}{l}\text { Entity } \\
\text { Type }\end{array}$} & \multicolumn{3}{|c|}{ Waiting Time (minutes) } & \multicolumn{3}{|c|}{ Transfer Time (minutes) } & \multicolumn{3}{|c|}{ Total Times (minutes) } \\
\hline & Average & Minimum & Maximum & Average & Minimum & Maximum & Average & Minimum & Maximum \\
\hline A1A & 2.49 & 0 & 9.6 & 5.09 & 1.08 & 6.11 & 7.98 & 3.00 & 16.52 \\
\hline $\mathrm{A} 1 \mathrm{~B}$ & 2.17 & 0 & 9.40 & 5.16 & 1.34 & 11.74 & 7.09 & 3.02 & 18.50 \\
\hline $\mathrm{A} 1 \mathrm{C}$ & 3.06 & 0 & 7.99 & 4.75 & 1.84 & 8.16 & 6.62 & 3.14 & 11.74 \\
\hline A2D & 2.51 & 0 & 9.46 & 5.35 & 2.20 & 7.50 & 6.15 & 2.81 & 12.56 \\
\hline $\mathrm{A} 2 \mathrm{E}$ & 3.94 & 0 & 19.58 & 5.15 & 1.79 & 4.17 & 7.89 & 2.32 & 23.82 \\
\hline $\mathrm{A} 2 \mathrm{~F}$ & 4.25 & 0 & 12.52 & 4.57 & 1.45 & 5.96 & 8.45 & 1.62 & 18.20 \\
\hline $\mathrm{A} 3 \mathrm{U}$ & 4.39 & 0 & 14.81 & 3.01 & 0.44 & 10.77 & 8.20 & 1.32 & 20.88 \\
\hline D1A & 2.16 & 0 & 10.62 & 5.98 & 1.70 & 11.02 & 10.02 & 5.85 & 19.15 \\
\hline D1B & 3.24 & 0.11 & 13.29 & 5.60 & 1.28 & 11.34 & 10.30 & 4.10 & 20.40 \\
\hline D1C & 2.57 & 0 & 12.49 & 3.62 & 1.31 & 8.10 & 8.33 & 2.50 & 20.20 \\
\hline D2D & 1.32 & 0 & 5.54 & 2.01 & 0.72 & 5.08 & 5.30 & 2.90 & 8.49 \\
\hline $\mathrm{D} 2 \mathrm{E}$ & 2.01 & 0 & 4.67 & 3.53 & 1.06 & 7.15 & 6.44 & 3.46 & 9.28 \\
\hline D2F & 1.71 & 0 & 8.99 & 3.84 & 1.00 & 6.11 & 7.38 & 4.07 & 15.04 \\
\hline D3U & 1.91 & 0 & 8.49 & 4.43 & 1.51 & 8.48 & 8.06 & 3.67 & 16.97 \\
\hline
\end{tabular}


From Table 5, the sum of waiting time, transfer time, and total time for the aircraft that would depart from and arrive at each terminal is shown. The time that has blue color are the entities type that had higher time than the rest of the result.

The highest average waiting time happened in entity A3U, when the aircraft landing and heading to Terminal 3 Ultimate. The highest maximum waiting time happened in A2E entity when the aircraft landing and heading to Terminal 2E. The highest average transfer time showed at D1A entity when the aircraft will take off and its origin terminal is Terminal 1A. The highest maximum transfer time showed from A1B entity when the aircraft landing and heading to Terminal 1 B.

The highest average total time happened in entity D1B, when the aircraft will take off and its origin terminal is Terminal 1B. The highest maximum total time happened in A2E entity when the aircraft landing and heading to Terminal 2E.

Table 6. Waiting time at hold area.

\begin{tabular}{|c|c|c|c|c|c|c|c|}
\hline \multirow{2}{*}{ Hold Area } & \multicolumn{3}{|c|}{ Waiting Time (minute(s)) } & \multirow{2}{*}{ Hold Area } & \multicolumn{3}{|c|}{ Waiting Time (minute(s)) } \\
\hline & Average & Min & Max & & Average & Min & Max \\
\hline Hold 29.Queue & 0.24 & 0 & 3.53 & Hold NCY1.Queue & 0.31 & 0 & 3.74 \\
\hline Hold 30.Queue & 0.13 & 0 & 2.36 & Hold NCY2.Queue & 0 & 0 & 0.18 \\
\hline Hold 32.Queue & 0.44 & 0 & 2.27 & Hold NCZ2.Queue & 0 & 0 & 0 \\
\hline Hold 46.Queue & 3.33 & 0.03 & 17.55 & Hold NPW.Queue & 0 & 0 & 0.25 \\
\hline Hold 31.Queue & 0.09 & 0 & 1.00 & Hold NCZ1.Queue & 0.38 & 0 & 7.59 \\
\hline Hold 58.Queue & 0.01 & 0 & 0.24 & Hold SC31.Queue & 0 & 0 & 0.01 \\
\hline Hold arr 07R.Queue & 2.55 & 0.06 & 8.26 & Hold SC41.Queue & 0.01 & 0 & 0.26 \\
\hline Hold N7.Queue & 0.20 & 0 & 1.94 & Hold SC51.Queue & 0 & 0 & 0 \\
\hline Hold NC21.Queue & 0.45 & 0 & 2.87 & Hold SPW.Queue & 0.01 & 0 & 0.32 \\
\hline Hold NC41.Queue & 0.51 & 0 & 6.75 & Hold NC52.Queue & 0.01 & 0 & 0.22 \\
\hline Hold NC42.Queue & 0.52 & 0 & 7.27 & Hold NCM1.Queue & 0.24 & 0 & 4.00 \\
\hline Hold NC51.Queue & 0.26 & 0 & 7.26 & Hold NCX1.Queue & 0 & 0 & 0.23 \\
\hline Hold N71.Queue & 0.33 & 0 & 2.16 & Hold SCX1.Queue & 0.01 & 0 & 0.29 \\
\hline Hold WC1 2.Queue & 0.04 & 0 & 0.74 & & & & \\
\hline
\end{tabular}

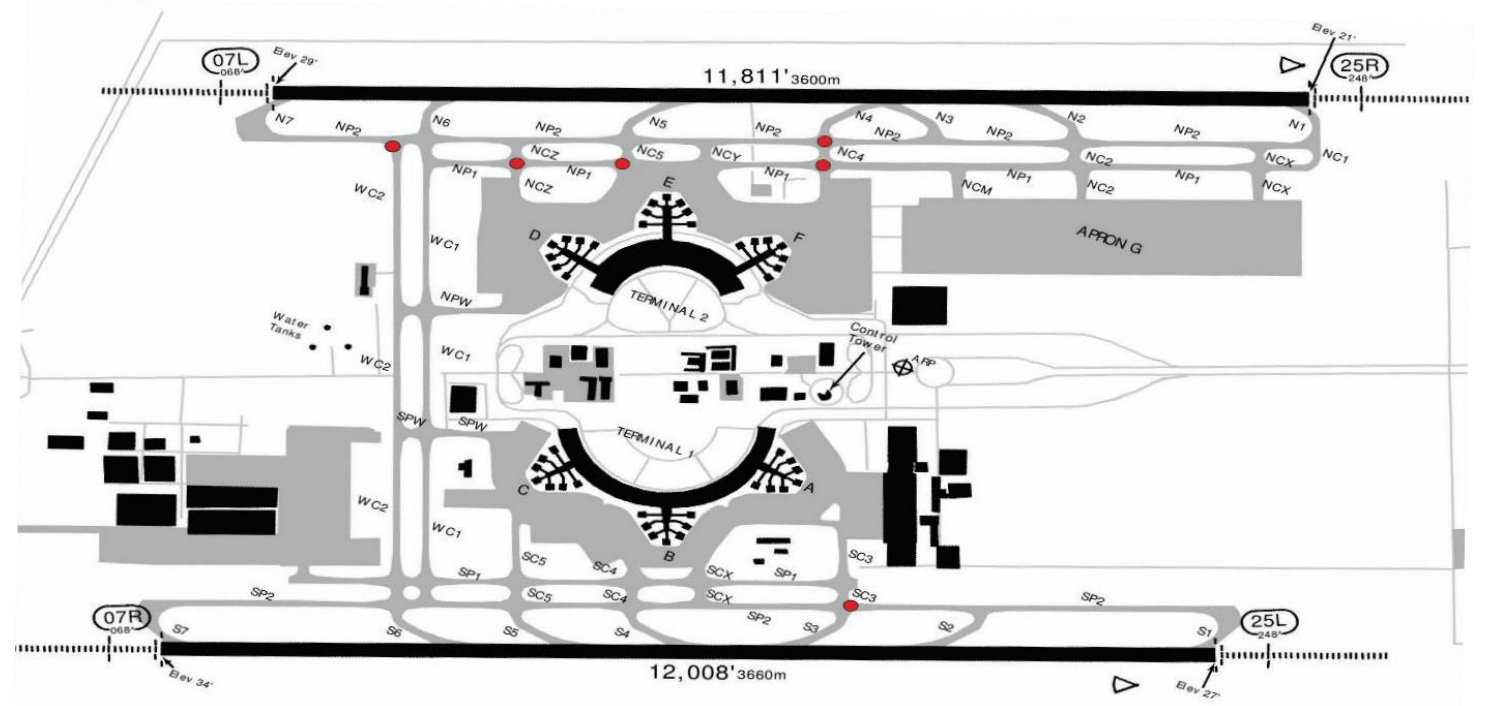

Figure 2. Holding area with waiting time more than 5 minutes. 
From waiting time data in Table 6, we could mark the holding areas that have waiting time more than 5 minutes. These areas will be shown as red spots in Figure 2. The areas that have waiting time more than 5 minutes are:

1. Hold 46, the intersection between taxiway WC1 and taxiway NP2,

2. Hold arr 07R, the intersection between taxiway SP2 and taxiway SC3,

3. Hold NC41, the intersection between taxiway NC4 and taxiway NP1,

4. Hold NC42, the intersection between taxiway NC4 and taxiway NP2, and

5. Hold NC51, the intersection between taxiway NC5 and taxiway NP1.

\section{Analyzation and Case Study}

The simulation's result in the previous section shows the entity that has high waiting time, and the path could be seen in Table 1 and Table 2. From the existing taxiing route, there are 5 intersections that have waiting time over than 5 minutes. This result the total time of the aircraft need for taxiing could be exceeding 20 minutes. High waiting time impacted by the parallel taxiway that not used efficiently in each runway side.

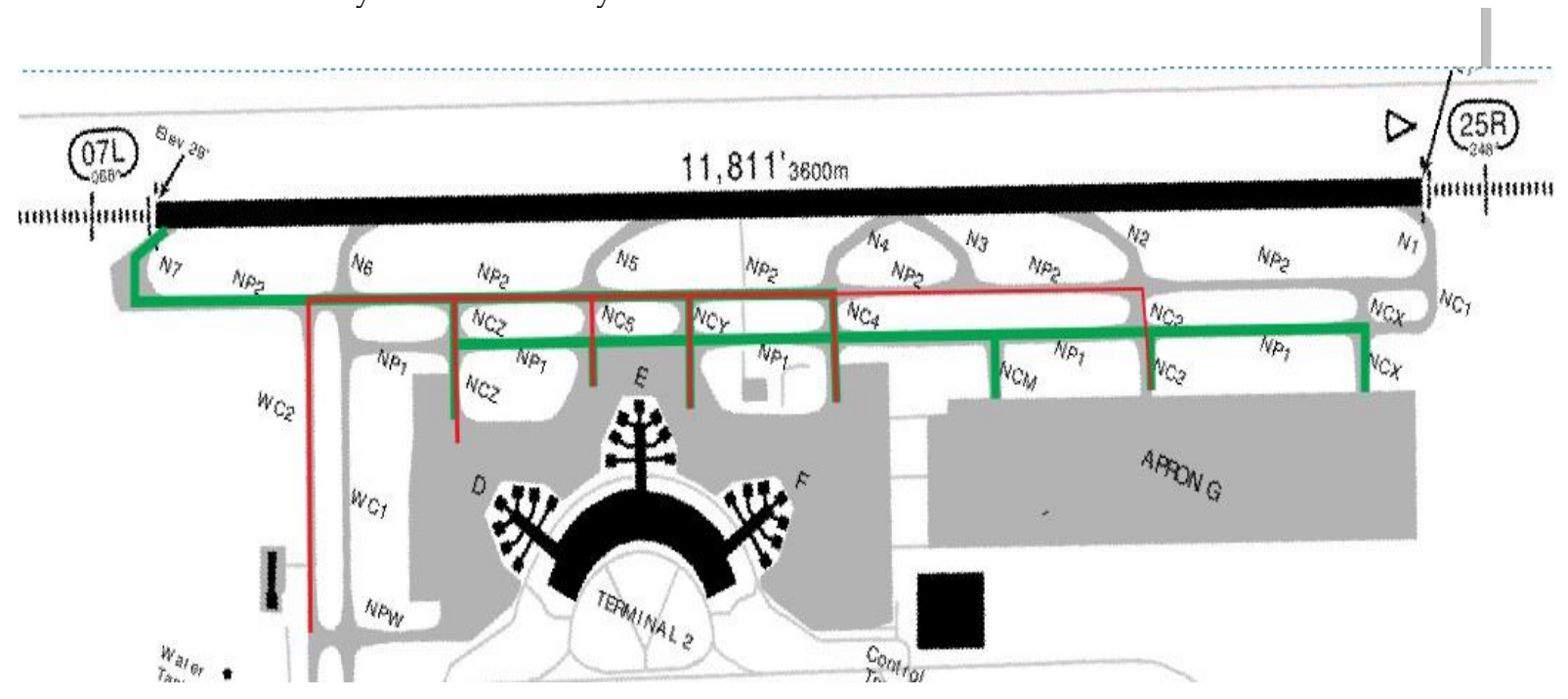

Figure 3. Taxiing route path at Soekarno-Hatta Intl Airport's north side.

From Figure 3, the green path shows taxiing route path for the aircraft that will take-off at runway 07L from Terminal 2 and Terminal 3 Ultimate. The red path shows taxiing route path for the aircraft that will be landing from runway 07R to Terminal 2 and Terminal 3 Ultimate. From this illustration, it shows that parallel taxiway NP2 used by the aircraft from two different directions, so if there are aircraft that will be take-off at runway 07L from Terminal 2 or Terminal 3 Ultimate, the aircraft that already landed at runway 07R and heading to Terminal 2 and Terminal 3 has to wait in taxiway WC2.

This may add more waiting time in taxiway WC2, it would take longer even more if the aircraft that will be take-off came from Terminal 3 Ultimate. On the south side also has the same problems with the north side. It showed in Figure 4, the red path shows taxiing route path for the aircraft that landed in runway $07 \mathrm{~L}$ and heading to Terminal 1 . The blue path shows the taxiing route path for the aircraft that landed at runway $07 \mathrm{R}$ and heading to Terminal 1, 2 and Ultimate 3. 


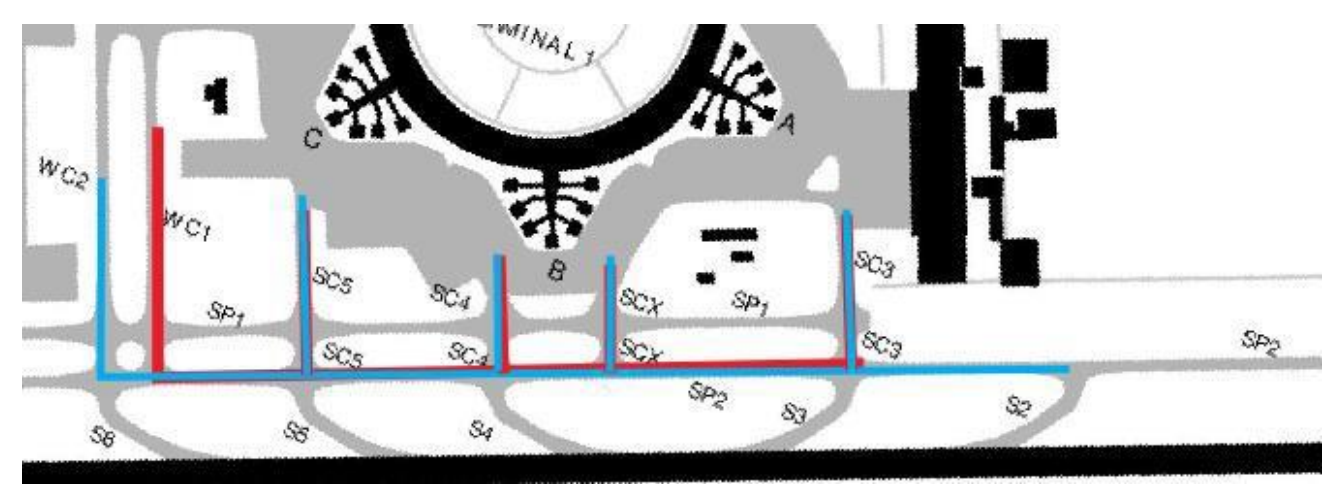

Figure 4. Taxiing route path at Soekarno-Hatta Intl Airport's south side.

From the illustration, it shows that parallel taxiway SP2 used by the aircraft from two different directions, so if there are aircraft landed at runway 07L and heading to Terminal 1, the aircraft have to wait at the intersection between taxiway SC3 and taxiway SP3.

\subsection{Improvement Route}

Because of the problems at runway $07 \mathrm{~L}$ and $07 \mathrm{R}$ are impacted by the parallel taxiway that used by two different paths, we propose to each side parallel taxiway used by one path only, so the aircraft not needed to waiting for other aircraft to passed from another direction. For the north side, taxiway NP2 should be used just for taxiing route from the west to the east side.

For the taxiway NP1, it should be used just for taxiing route from the east to the west side. For the south side, taxiway SP2 should be used just for the taxiing route from the east to the west side and taxiway SP2 should be used just by the taxiing route from the west to the east side, as presented on Figure 5 and Figure 6.

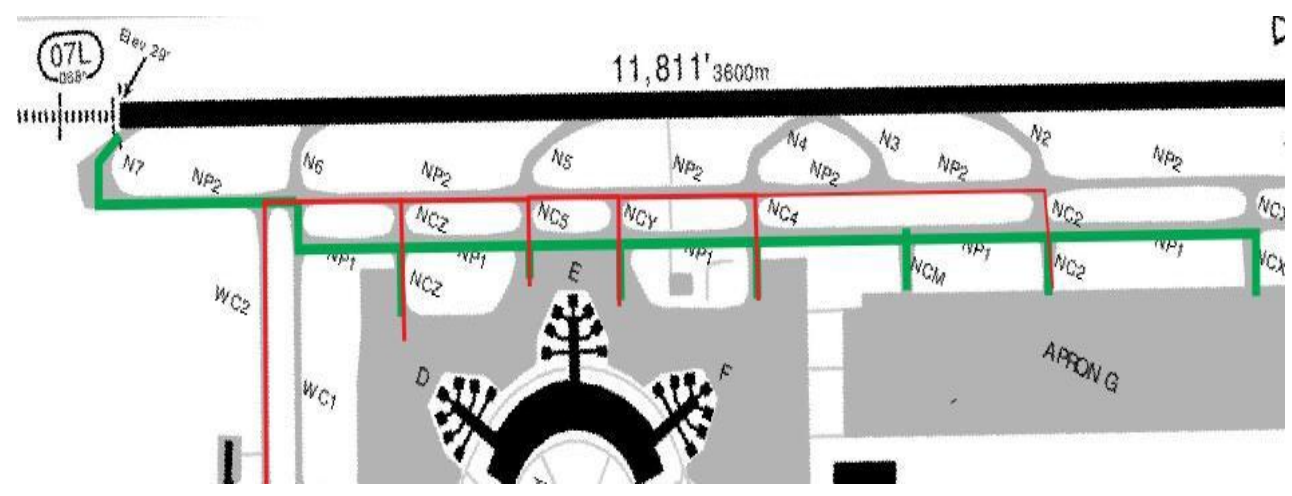

Figure 5. Improved taxiing route path at Soekarno-Hatta Intl Airport's north side

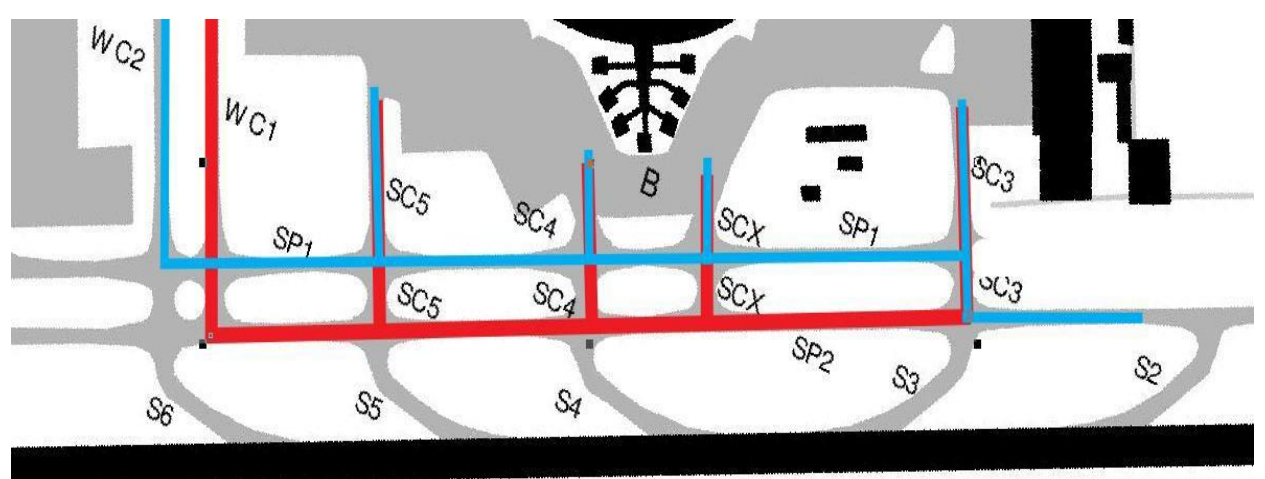

Figure 6. Improved taxiing route path at Soekarno-Hatta Intl Airport's north side 
With the improved taxiing route in Figure 5 and Figure 6, the duration of waiting time would be shorter. This caused by the queue to take turns between two aircraft from different directions is just from taxiway SP1 to taxiway SP2 in the south side. The same happened at the north side, the taxiing waiting distance will be shorter so other aircraft will not have a long queue, just from taxiway WC1 to taxiway WC2, as presented on Figure 7 and Figure 8. These results is in the same agreement to others $[8,9]$.

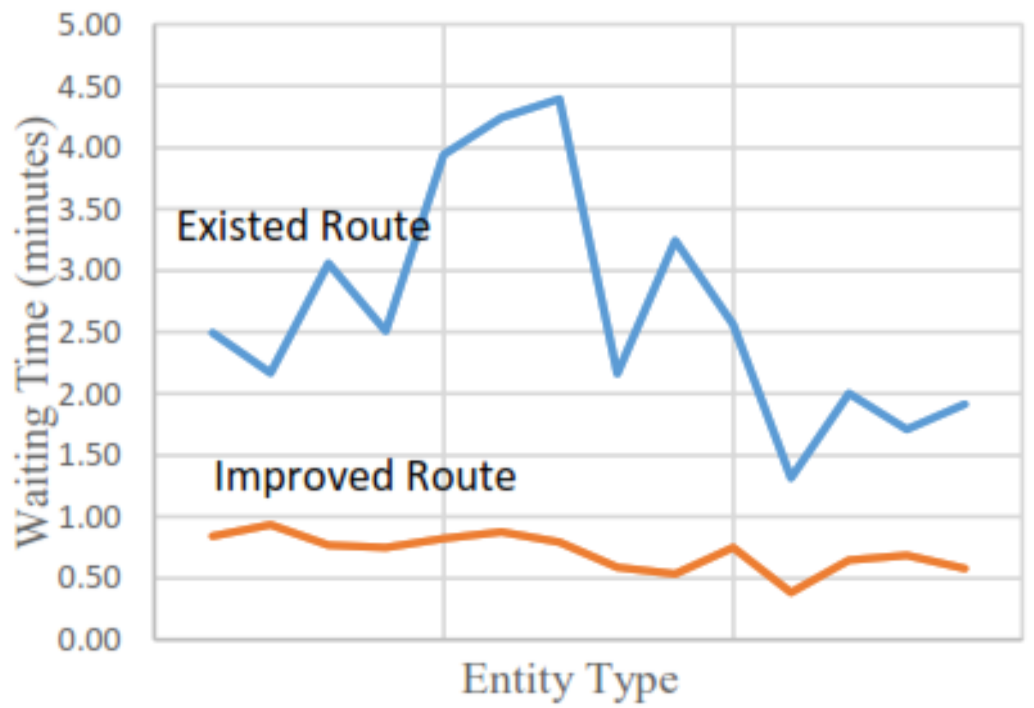

Figure 7. Average waiting time comparison between existed route and improved route

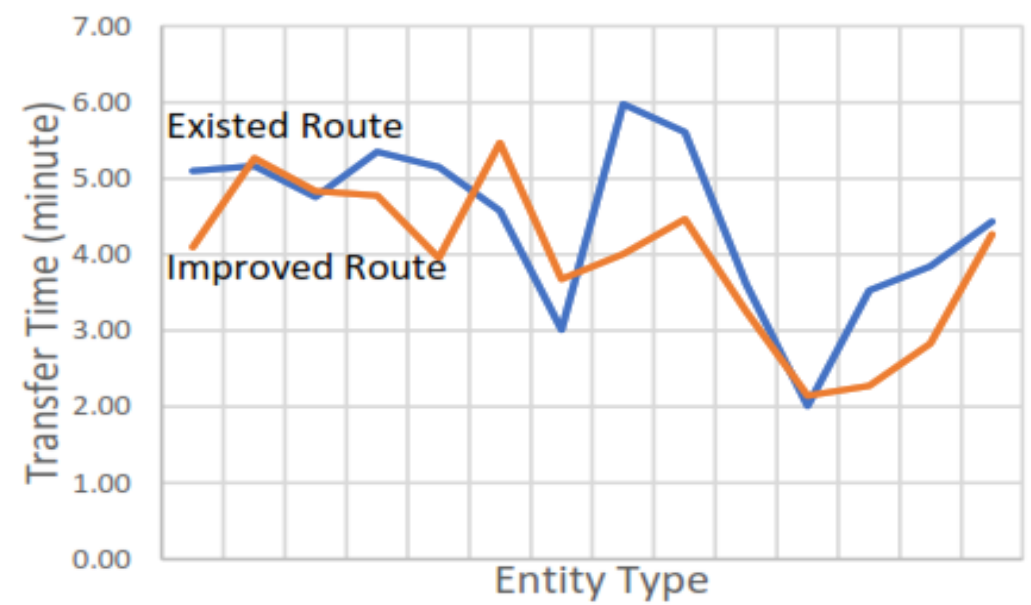

Figure 8. Average transfer time comparison between existed route and improved route

\section{Conclusions}

This study has improved a taxiing route, shorter duration of waiting time, and improved the aircraft queue from different directions is just from taxiway in the south sides. The same happened at the north side, the taxiing waiting distance will be shorter so other aircraft will not have a long queue. This model may be applied to other airports for scheduling aircraft's departing and arriving, develop airport airside facility, and reducing the taxiing duration of the aircraft significantly. 


\section{References}

1. Neufville, Richard L., dan Dr. Amedeo R. Odoni. 2013. Airport Systems, Second Edition: Planning, Design and Management (Mechanical Engineering) 2nd Edition.

2. Sanderson, Jeppesen. 2016. Airport Information for WIII.

3. Vullers, Jansen, Ijpelaar, Loosschilder, M.W.N.C. 2006. Workflow patterns modelled in Arena.

4. International Civil Aviation Organization (ICAO) Doc. 9157, Aerodrome Design Manual, Part 2: Taxiway, Apron, and Holding Bay.

5. Federal Aviation Administration (FAA). AC 91-73 part 141.

6. ARENA-UM001B-EN-P. 2005. Arena User's Guide.

7. Boeing, Boeing 737 NG Flight Crew Manual.

8. Riverside Municipal Code. AIRCRAFT REGULATIONS, section: 12.08.100 Taxi speed.

9. Didi. 2017. Verifikasi dan Validasi Sistem Simulasi. [online] didi.staff.gunadarma.ac.id accessed in 25 Juli 2017.

This is an open-access article distributed under the terms of the Creative Commons Attribution 4.0 International License, which permits unrestricted use, distribution, and reproduction in any medium provided the original work is properly cited. 